\title{
Combined effect of infection and heavy wrapping on the risk of sudden unexpected infant death
}

\author{
Ruth Gilbert, Peter Rudd, P Jeremy Berry, Peter J Fleming, Elizabeth Hall, Diana G White, \\ Vivian O C Oreffo, Peter James, Julie Ann Evans
}

\begin{abstract}
Three methods were used to investigate the role of infection in sudden unexpected infant death (SUD): (i) microbiological comparison of SUD victims and matched, live, community controls; (ii) postmortem classification of the contribution of infection to death; and (iii) case-control analysis of the relative risk associated with both infection and heavy wrapping.

Limited sampling from the upper respiratory tract and gut in SUD victims and controls showed no significant excess of viral infection in the SUD victims (odds ratio $=1.98,95 \%$ confidence interval (CI) 0.9 to 4.5 ). At postmortem examination, infection explained death in 3/95 babies and may have contributed to death in $37 / 95$.

Over 70 days of age, the combined presence of viral infection and wrapping in excess of 10 togs produced an odds ratio of SUD of 51.5 (95\% CI 5.64 to 471.48 ) compared with wrapping of less than 6 togs.

Viral infection was not a major risk factor as long as babies were lightly wrapped. In heavily wrapped babies the presence of a viral infection greatly increased the risk of SUD.
\end{abstract}

Infection is a common finding in babies dying suddenly and unexpectedly (SUD)..$^{1-8}$ In a small proportion, overwhelming infection is clearly the cause of death, but in the majority it is uncertain whether infection contributes to death or not. ${ }^{8}$

Previous studies have failed to determine whether infection occurs more commonly in SUD victims than in similar infants living in the same community at the same time. ${ }^{1} 2$ 5-7 Furthermore, pathologists vary considerably in their interpretation of postmortem findings. 910 Lack of control babies for postmortem examination of a similar age who die from accidents has made it difficult to establish a consistent classification of those findings which explain death, contribute to death, or are non-contributory.

Although minor respiratory tract infections are the most common finding in SUD victims, there has been no association between SUD and any one particular organism. ${ }^{1-8}$ Consequently, if infection is associated with SUD, the mechanism may be related to factors common to infection in general, such as an increase in metabolic rate and body temperature or to effects on airway patency. ${ }^{11}$ It is possible that infection interacts with other environmental or physiological factors known to be associated with SUD, such as heavy wrapping or prone sleeping, to precipitate SUD in some babies. ${ }^{12-15}$

In order to assess the role of infection in SUD we have investigated the incidence of infection in SUD victims and matched controls from the same community. Secondly, we have established criteria for a classification of postmortem findings to reflect contribution of infection to death. Lastly, we have investigated the combined presence of infection and heavy wrapping on the risk of SUD.

\section{Methods}

Important features of the study design were that: all SUD victims within a defined geographical area were investigated, specimens were collected and parents were interviewed as soon as possible after discovery of death, and live control babies were matched for age, neighbourhood, and time of year. ${ }^{12}$

\section{INDEX BABIES}

From May 1987 until the end of April 1989, all babies between the age of 1 week and 2 years who died suddenly and unexpectedly within Avon and north Somerset were eligible for inclusion in the study.

\section{Collection of specimens}

An initial set of specimens was taken within a median time of 3.5 hours from the discovery of death (range 0.25-46 hours). Specimens included: nasopharyngeal aspirate, tracheal aspirate, four throat swabs taken simultaneously (last 58 cases only), blood taken from the sagittal sinus (all cases) and from the heart (last 70 cases only), and cerebrospinal fluid obtained by cisterna magna puncture. Urine was obtained if possible by suprapubic aspirate and a stool specimen was collected when available. Specimens were immediately transported to the laboratory and processed.

Further tissue samples and swabs of all major organs were taken at full postmortem examination, which was performed within a median time of 25 hours (range 2:8-73 hours) after discovery of death. The postmortem protocol was similar to that described by Wigglesworth $e t$ $a l .{ }^{16}$

\section{Interviews}

As part of the bereavement counselling, parents were seen by one of the investigators usually within hours of discovery of death. A detailed medical history was taken including recent signs 
of illness noted by the parents. Major signs were classified as those indicative of serious illness or needing a medical opinion such as drowsiness, persistent cough, or missing more than one feed. ${ }^{17}$ Hospital records were scrutinised for any additional clinical and demographic information. For the latter 18 months of the two year study, detailed questions were asked about the quantity and type of clothing and bedding covering the baby and the position in which the baby was lying when found dead and when put to bed. Tog values for clothing and bedding were calculated as previously described. ${ }^{12}$ Information on daily maximum and minimum temperatures in Avon for the period of the study was supplied by the Meterological Office.

\section{CONTROL BABIES}

The next two babies born within two weeks on the same health visitor list as the index case were selected as controls. Control families were visited within a median time of 70 hours from the discovery of death (range 8-324 hours).

Four throat swabs and a stool specimen were collected and processed in the same way as for the index cases. Parents were asked to save a stool specimen for collection. In 23/190 cases, no stool specimen was received.

Control parents had similar detailed interviews to the index parents. Questions were asked about clothing, bedding, and the sleeping position during the night before interview.

\section{LABORATORY TESTS}

Viral isolation was carried out using standard cell culture and identification techniques on the following cell lines: Hep 2, baboon kidney, MRC5, and C16. Nasopharyngeal aspirates were examined using immunofluorescent microscopy with monoclonal antibodies to respiratory syncytial virus, adenovirus, influenza virus types $\mathrm{A}$ and $\mathrm{B}$, cytomegalovirus, parainfluenzae virus types $1-3$, herpes simplex virus, measles virus, and Chlamydia trachomatis. Throat swabs were similarly examined using monoclonal antibodies to $C$ trachomatis. Faecal extracts were subjected to tissue culture and inoculated into suckling mice to culture coxsackie A virus. Faeces or large intestinal contents were examined for viruses using standard electron microscopy techniques.

Routine bacteriology was carried out on all swabs and gastrointestinal specimens. Selective media were used to culture Staphylococcus aureus, Streptococcus sp, Bordetella pertussis, Campylobacter $\mathrm{sp}^{18}$ Clostridium botulinum, ${ }^{19}$ Clostridium difficile, $C$ trachomatis, ${ }^{20}$ Ureaplasma urealyticum, and Mycoplasma hominis. ${ }^{21}$ Botulinum toxin was detected by inoculation of faeces supernatant or extract into suckling mice. Cytotoxin testing was performed using vero cell monolayers together with DNA probes for verocytotoxin genes VT1 and VT2. ${ }^{22}$ Where appropriate, organisms were typed using commercial kits followed by reference laboratory analysis.

\section{CLASSIFICATION OF FINDINGS AT POSTMORTEM EXAMINATION}

All postmortem examinations were carried out by one of two pathologists (PJB, EH). Histological findings at six sites in the respiratory tract were reviewed and graded in all cases by PJB without knowledge of any details of the case: grade 0 normal, grade 1 mild inflammation, grade 2 moderate inflammation, and grade 3 severe inflammation.

Histological and microbiological findings for all 95 SUD victims were correlated and criteria developed for three broad categories of SUD: I: no significant findings, II: findings that may have contributed to death, and III: death fully explained by findings. These categories were further subdivided (see table 1).

All pathological, microbiological, and metabolic results were reviewed for each baby at a multidisciplinary meeting which included two pathologists, three microbiologists, and three paediatricians. Microbiological, histological, and metabolic findings were classified separately and the highest grade allocated as the overall category for each baby as shown in table 1 .

\section{STATISTICAL ANALYSIS}

The Mantel and Haenszel triplet test was used

Table 1 Example of categorisation in a 61 day old SUD victim: adenovirus type 5 isolated from the large intestine but with no evidence of gastroenteritis (IB), C trachomatis identified in the nasopharynx and trachea (IIA), grade 1 inflammation on lung histology (IB), no abnormal metabolic findings (IA). Overall category allocated was IIA based on microbiological findings

\begin{tabular}{|c|c|c|c|}
\hline Category definitions & Histopathological criteria & Microbiological criteria & Metabolic criteria \\
\hline $\begin{array}{l}\text { IA: No abnormal findings } \\
\text { IB: Non-contributory findings }\end{array}$ & $\begin{array}{l}\text { No abnormal findings } \\
\text { Grade } 1-3 \text { inflammation of URT, } \\
\text { grade } 1 \text { inflammation of LRT, } \\
\text { purulent exudate-middle ear, } \\
\text { minor congenital anomalies }\end{array}$ & $\begin{array}{l}\text { No abnormal findings } \\
\text { Bacterial pathogens in LRT, } \\
\text { non-pathogenic bacteria in blood } \\
\text { (for example, coagulase negative } \\
\text { staphylococci), virus excretion } \\
\text { (for example, from faeces or } \\
\text { urine), polio virus-any site } \\
\text { except CSF }\end{array}$ & $\begin{array}{l}\text { No abnormal findings } \\
\text { For example, raised octanoic } \\
\text { acid in CSF }\end{array}$ \\
\hline $\begin{array}{l}\text { IIA: Associated findings, which } \\
\text { may have contributed to death }\end{array}$ & $\begin{array}{l}\text { Grade } 2-3 \text { inflammation of LRT, } \\
\text { significant inflammation at other } \\
\text { sites-for example, urinary tract }\end{array}$ & $\begin{array}{l}\text { Bacterial pathogens isolated from } \\
\text { blood or in heavy growth from } \\
\text { liver and spleen or kidney, } \\
\text { polio virus in CSF, C trachomatis } \\
\text { in respiratory tract }\end{array}$ & $\begin{array}{l}\text { Vitreous humour sodium }<126 \text { or } \\
>150 \mathrm{mmol} / \mathrm{l} \text {, urea }>8.0 \mathrm{mmol} / \mathrm{l} \text {, } \\
\text { isolated metabolic defect, } \\
\text { (for example, glycogen storage } \\
\text { disease type Ic) }\end{array}$ \\
\hline $\begin{array}{l}\text { IIB: Extensive/severe associated } \\
\text { findings but not a complete } \\
\text { explanation for death }\end{array}$ & $\begin{array}{l}\text { Extensive grade } 3 \text { inflammation } \\
\text { of LRT }\end{array}$ & $\begin{array}{l}\text { Bacterial pathogens in blood, liver, } \\
\text { and spleen }\end{array}$ & $\begin{array}{l}\text { Metabolic defect with evidence of } \\
\text { substrate accumulation }\end{array}$ \\
\hline $\begin{array}{l}\text { III: Death fully explained } \\
\text { by findings }\end{array}$ & $\begin{array}{l}\text { Severe disease-for example, } \\
\text { purulent meningitis, pyelonephrosis, } \\
\text { major heart defect }\end{array}$ & Bacterial pathogens in CSF & $\begin{array}{l}\text { Raised serum ammonia }>150 \mathrm{mmol} / \mathrm{l} \text {, } \\
\text { major metabolic defect }\end{array}$ \\
\hline
\end{tabular}


to compare qualitative variables in index cases with two matched controls. ${ }^{23} \mathrm{~A}$ modified form of this test was used where a variable number of controls were analysed. ${ }^{24}$ Continuous variables were analysed using the paired $t$ test or the Wilcoxon rank test by comparing index cases with the mean of the two matched controls. Interaction between variables was assessed using a matched multiple logistic regression programme which retained index case matching with the control pairs. ${ }^{25}$

\section{Results}

A total of 109 babies died suddenly and unexpectedly during the two year study period of which 95 were investigated. Fourteen were excluded mainly because of late notification to the investigators. Microbiological, pathological, clinical, and social information was collected for these 14 excluded babies and did not differ from the study group.

Of the 95 SUD victims investigated, an explanation for death was found in 7/95 (8\%): intracranial haemorrhage, Reye's syndrome, heart failure secondary to an atrioventricular canal defect, gastric perforation, $S$ aureus septicaemia, Haemophilus influenzae meningitis, and severe rotavirus gastroenteritis. The remaining $88 / 95$ cases were classified as sudden infant death syndrome (SIDS). ${ }^{26}$ One of these 88 SIDS victims was resuscitated and ventilated for 24 hours before brainstem death was confirmed. Of the 95 index babies, information on sleeping position and clothing and bedding was available in 72 SUD victims and 144 matched controls. Five of 72 of these deaths were explained. This subgroup of 72 SUD victims did not differ significantly from the overall study population of 95 index babies.

The median age for the 95 index babies was 94 days (range 7-551) and for the 190 controls 96.5 days (range 18-552); difference 2.5 days, $95 \%$ confidence interval (CI) 1.5 to 3.75 days. The age distribution appeared to be bimodal with peaks in incidence at 40-60 and 80-130 days and a trough at 70 days (see fig 1). In

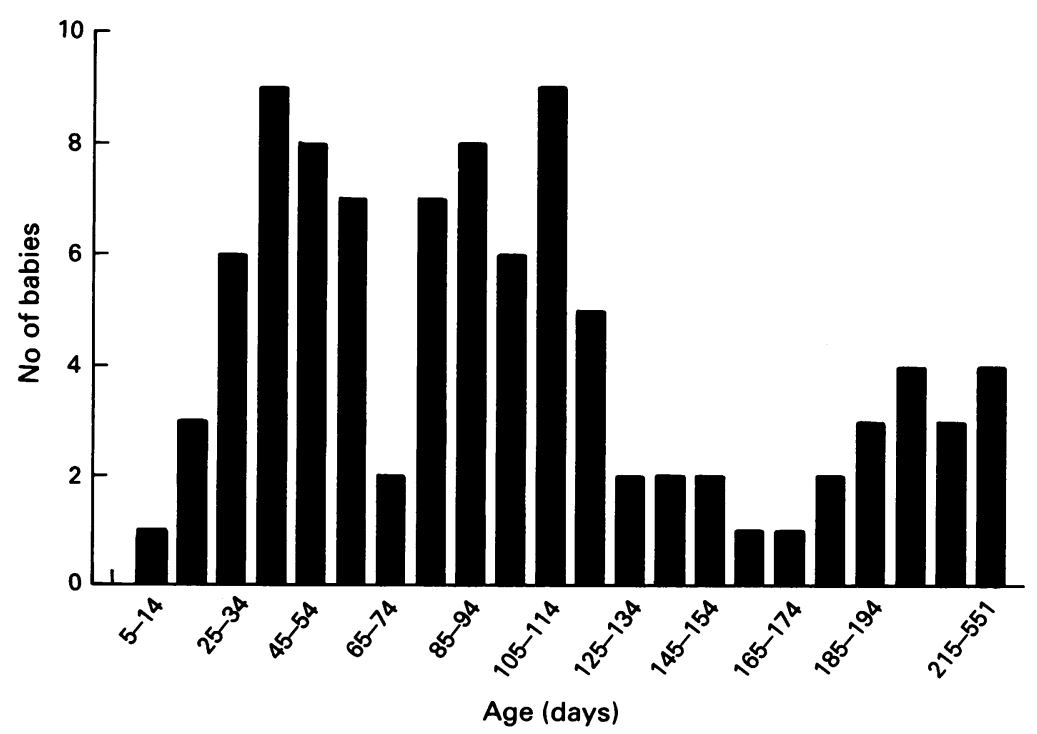

Figure I Agedistribution of SUDvictims. subsequent analysis the effect of age is assessed by comparison of babies older and younger than 70 days of age. Ninety of $95(95 \%)$ index babies were less than 210 days ( 30 weeks) when they died.

Index babies were lighter at birth with a mean birth weight of $3230 \mathrm{~g}$ (range 1310-4640) compared to the control babies with $3400 \mathrm{~g}$ (range 1790-4840); mean difference $170 \mathrm{~g}(95 \%$ CI: 0.016 to $0.324, p=0.03$ ). The mean gestation in the index group was 38.9 weeks (range $32-42$ ) and in the control group $39 \cdot 8$ weeks (range 34-43); mean difference 0.86 weeks (95\% CI: 0.36 to $1.36, \mathrm{p}<0.001$ ).

The male to female ratio was $1 \cdot 6: 1$ and $1: 1$ in the index and control groups respectively. Index babies were significantly more likely to have one or more siblings (72/95) compared to controls $(111 / 190) ; \chi^{2}=11 \cdot 2, p<0.001$. Too few babies had viral infections to determine whether infection occurred significantly more commonly among babies with siblings. Twenty three percent of the babies in both groups had received their polio immunisation within the previous 60 days.

Socioeconomic classification (Registrar General's classification group I-V) was similar in both index and control groups, but there was an excess of unemployed parents in the index group: odds ratio $3 \cdot 3,95 \% \mathrm{CI}: 1.6$ to $7 \cdot 0$ $(\mathrm{p}<0.01)$.

Sixty out of 95 of the SUD victims (63\%) died during the six month period from October to March, the peak incidence being in March. There was no relationship between age at death and season; 24/35 (69\%) of SUD victims less than 70 days died during the six winter months, compared with $36 / 60$ of those over 70 days old.

MICROBIOLOGY RESULTS BASED ON COMPARISON OF SUD VICTIMS AND CONTROLS

Comparison of microbiological results was based on similar specimens taken from the upper respiratory and gastrointestinal tracts. In addition to throat swabs and stool specimens, nasopharyngeal aspirates and specimens of intestinal mucosa were taken from index babies.

\section{Viruses}

Results of viruses detected are shown in table 2 . Excluding those babies from whom no stool specimens were obtained, the odds ratio for sudden death associated with non-polio virus detection was 1.96 (95\% CI: 0.9 to $4.5, p>0.05)$. Types of viruses identified in both groups were predominantly adenoviruses and enteroviruses. In both the index and control groups, $85 \%$ $(13 / 15)$ of the virus positive babies were over 70 days old. Of the virus infected SUD victims, $7 / 15$ were girls as were $10 / 15$ of the virus infected controls $(p>0 \cdot 05$.).

\section{Bacteria}

The prevalence of potential bacterial pathogens in the upper respiratory tract in the SUD victims and control babies is shown in table 3 . There was no association between isolation of 
these organisms and sampling time: median time from discovery of death for pathogen positive babies was 3.87 hours (range $1 \cdot 5-45 \cdot 7$ ) and for pathogen negative babies 3.2 (range $0.25-30$ ) (difference $0.67,95 \% \mathrm{CI}:-0.28$ to $1.55 ; \mathrm{p}>0.05$ ).

Faeces from 1/90 index and 1/164 control babies were positive for cytotoxin which was not neutralised by antisera to $C$ difficile : one control baby was culture positive for Escherichia coli 074.H28 and the verocytotoxin gene 2 (VT2) probe. One index baby was positive for

Table 2 Micro-organisms detected in SUD victims and controls (number of samples included in each analysis shown in square brackets)

\begin{tabular}{|c|c|c|c|}
\hline \multirow{2}{*}{$\begin{array}{l}\text { Type of organism } \\
\text { or toxin and } \\
\text { specimen site }\end{array}$} & \multicolumn{2}{|c|}{ No $(\%)$ of babies affected } & \multirow[t]{2}{*}{ p Value } \\
\hline & $\begin{array}{l}\text { SUD } \\
\text { victims }\end{array}$ & Controls & \\
\hline \multicolumn{4}{|l|}{ Non-polio viruses: } \\
\hline Gut * & \multirow{2}{*}{$\begin{array}{l}8(8) \\
{[n=95]} \\
10(11) \\
{[n=95]} \\
15(16) \\
{[n=95]}\end{array}$} & \multirow{2}{*}{$\begin{array}{l}10(5) \\
{[n=190]} \\
10(6) \\
{[n=167]} \\
15(8) \\
{[n=190]}\end{array}$} & $>0.05$ \\
\hline Total No virus positive & & & $>0.05$ \\
\hline $\begin{array}{l}\text { Polio viruses: } \\
\text { Upper respiratory tract }\end{array}$ & \multirow{3}{*}{$\begin{array}{l}5(5) \\
{[n=95]} \\
17(18) \\
{[n=95]} \\
17(18) \\
{[n=95]}\end{array}$} & \multirow{3}{*}{$\begin{array}{l}10(5) \\
{[n=190]} \\
25(15) \\
{[n=167]} \\
30(16) \\
{[n=190]}\end{array}$} & $>0.05$ \\
\hline Gut* & & & $>0.05$ \\
\hline Total No virus positive & & & $>0.05$ \\
\hline $\begin{array}{l}C \text { trachomatis in } \\
\text { upper respiratory tract }\end{array}$ & $\begin{array}{l}4(4) \\
{[n=95]}\end{array}$ & $\begin{array}{l}0 \\
{[n=190]}\end{array}$ & $>0.05$ \\
\hline $\begin{array}{l}U \text { urealyticum or } M \text { hominis } \\
\text { in upper respiratory tract }\end{array}$ & \multirow{4}{*}{$\begin{array}{l}5(8 \cdot 5) \\
{[n=58]} \\
0 \\
{[n=95]} \\
0 \\
{[n=36]} \\
5(6) \\
{[n=85]}\end{array}$} & \multirow{4}{*}{$\begin{array}{l}6(5) \\
{[n=117]} \\
0 \\
{[n=167]} \\
0 \\
{[n=30]} \\
8(5 \cdot 5) \\
{[n=142]}\end{array}$} & $>0.05$ \\
\hline$C$ botulinum in gut ${ }^{*}$ & & & $>0.05$ \\
\hline$C$ botulinum toxin in gut* & & & $>0.05$ \\
\hline$C$ difficile toxin in gut" & & & $>0.05$ \\
\hline
\end{tabular}

*Denominator varies according to availability of sufficient specimen for testing.

tTwo cases were culture and immunofluorescence positive; two cases were immunofluorescence positive only.

Table 3 Potential bacterial pathogens isolated from the upper respiratory tract in SUD victims and controls

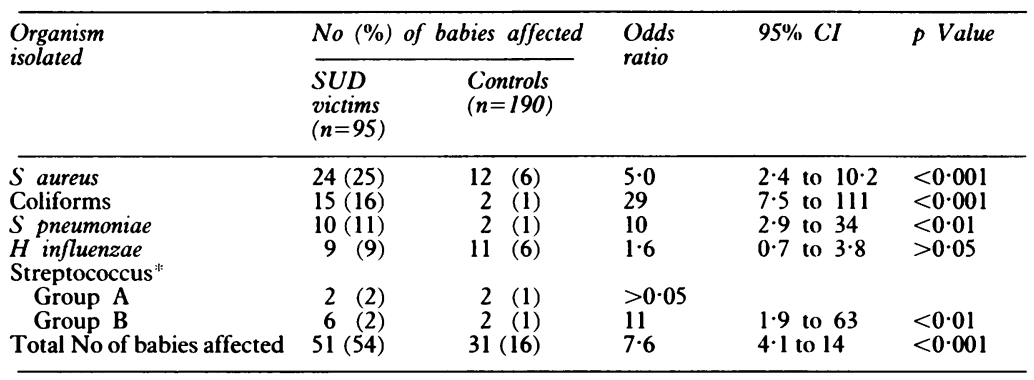

* $\beta$ Haemolytic streptococcus Lancefield group A or B. Note: for the first 37 index cases, results are from culture of nasopharyngeal aspirate, therafter, results refer to throat swabs only. cytotoxin to vero and $\mathrm{Y} 1$ cells but negative to VT1 and VT2 probes and neutralising antibodies.

We found no relationship between viruses and bacterial pathogens identified at the same site. Viruses were detected as frequently in the upper respiratory tract of babies who were positive for bacterial pathogens $(16 \%, 8 / 51)$ as in babies who had no potential bacterial pathogens isolated $(16 \%, 7 / 44)$.

\section{MICROBIOLOGICAL FINDINGS AT POSTMORTEM}

EXAMINATION: INDEX BABIES ONLY

Based on virological analysis of all organs, nonpolio viruses were indentified in 19/95 (20\%) babies and one further baby had poliovirus type 2 isolated from the cerebrospinal fluid. Non-polio viruses identified in order of frequency were adenovirus $(n=8)$, enterovirus $(n=3)$, rotavirus $(n=2)$, parainfluenzae virus type $3(n=2)$, cytomegalovirus $(n=2)$, measles $(n=1)$, and respiratory syncytial virus $(n=1)$. One further baby had congenital cytomegalovirus infection, demonstrated by positive urine culture at 3 weeks of age but was culture negative at postmortem examination at 5 months old. The type and distribution of bacterial pathogens is shown in table 4 . Nine babies had bacteraemia, in two cases both $H$ influenzae and Streptococcus pneumoniae were isolated.

\section{CLASSIFICATION OF FINDINGS AT POSTMORTEM EXAMINATION}

Results for all 95 SUD victims are given in table 5. Thirty nine of 95 babies were allocated category IIA or IIB, 37/39 due to evidence of recent infection. Of these 37 babies, 11 were graded IIA or IIB on account of both microbiological and histopathological findings. Of the remaining 26 babies allocated category IIA and IIB babies, nine babies, three of whom were graded for histopathology and six for microbiology, had no corroborative microbiology or histopathology findings respectively. Nine out of 35 of the SUD victims (26\%) less than 70 days old and $28 / 60(47 \%)$ of those over 70 days were allocated category IIA or IIB for evidence of infection $\left(\chi^{2}=4 \cdot 08, p<0 \cdot 05\right)$.

THERMAL INSULATION IN INDEX AND CONTROL BABIES

Of the 72 SUD victims and 144 controls, data

Table 4 Frequency and site of isolation of bacterial pathogens at postmortem examination

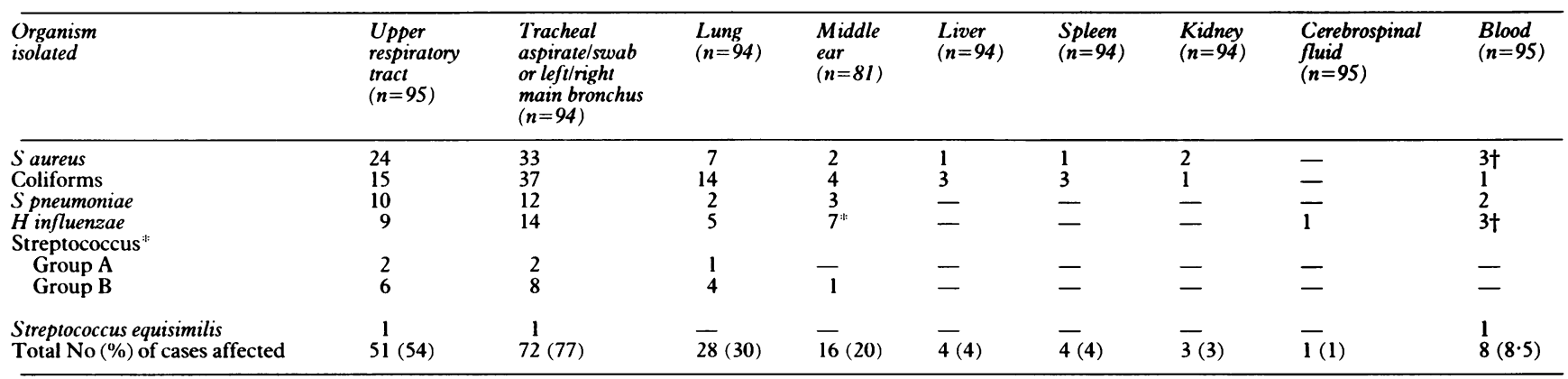


Table 5 Classification of findings at postmortem examination for 95 SUD victims

\begin{tabular}{|c|c|c|c|c|}
\hline \multirow[t]{2}{*}{ Category } & \multicolumn{3}{|l|}{ Classification } & \multirow{2}{*}{$\begin{array}{l}\text { Total } \\
\text { No }(\%) \text { of } \\
\text { cases }\end{array}$} \\
\hline & Microbiology & Histopathology & Metabolic & \\
\hline $\begin{array}{l}\text { IA } \\
\text { IB }\end{array}$ & 36 & 17 & 3 & \begin{tabular}{r|r}
6 & $49(51 \cdot 5)$ \\
43 &
\end{tabular} \\
\hline IIA & $\begin{array}{r}19 \\
1\end{array}$ & $\begin{array}{r}20 \\
4\end{array}$ & $\begin{array}{l}4 \\
0\end{array}$ & \begin{tabular}{r|r}
34 \\
5
\end{tabular} \\
\hline III & 2 & 7 & 1 & $7(7 \cdot 5)$ \\
\hline
\end{tabular}

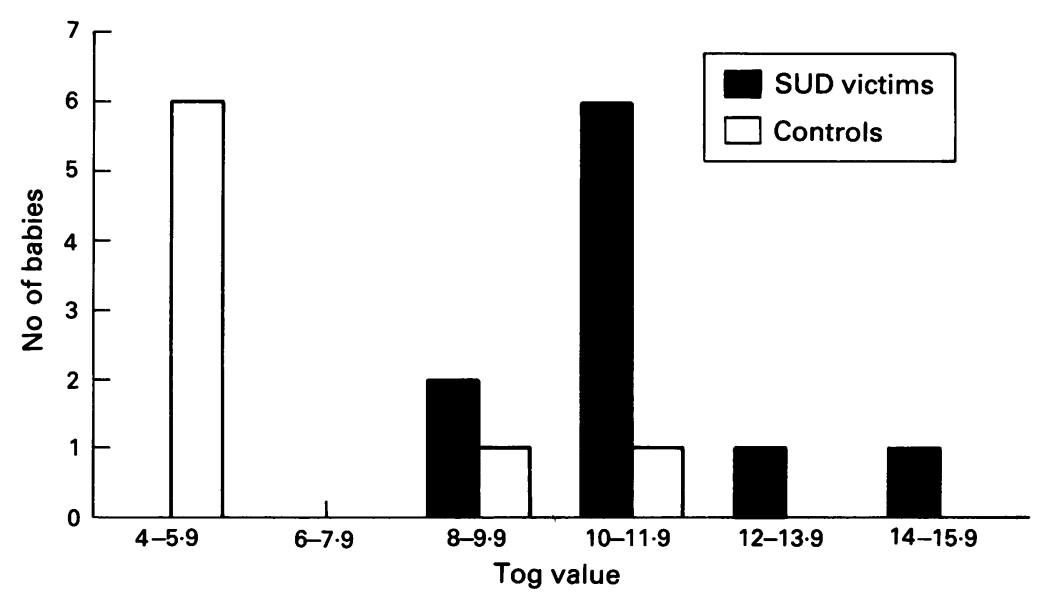

Figure2 Tog values invirus infectedSUDvictims and control babies.

were incomplete on clothing and bedding in four babies and on sleeping position in five index babies. The median age of the 72 SUD victims was 90 days (range 7-210 days) and of the controls 89 days (range 18-208 days). Forty four of the 72 SUD victims were aged over 70 days when they died.

For babies in whom thermal insulation data was complete, there was no significant difference between the virus infected SUD victims (10/68) and the virus infected controls $(8 / 136)$ in terms of age, birth weight, or minimum environmental temperature during the 24 hours preceding death or interview. Only one baby in each group was less than 70 days old.

\section{Tog values}

Thirty out of 68 of the SUD victims (44\%) and $37 / 136(26 \%)$ of their matched controls had calculated tog values greater than 10 togs $\left(\chi^{2}=5 \cdot 9, p<0 \cdot 02\right)$. Mean tog values were $9 \cdot 15$ and 8.0 for the index and control babies respectively, mean difference $1 \cdot 1$ togs $(95 \% \mathrm{CI}$ : $0 \cdot 15$ to $2 \cdot 2, p=0.025) .{ }^{12}$ Tog values for the babies with virus infections are shown in fig 2 .

The median tog values for all virus infected babies were 11.0 (range 9.1-14.7) for index babies $(n=10)$ and $5 \cdot 6$ (range 5.5-10.7) for controls $(n=8)$; difference 4.9 togs (range $3 \cdot 3-5 \cdot 6, p=0 \cdot 0016)$. There was no significant difference between the median tog values for all virus negative index babies, median tog 8.8 (range $0 \cdot 8-18 \cdot 4 ; \mathrm{n}=58$ ) and control babies, median tog 8.0 (range 1.9-16.5; $n=128$ ). Among babies over 70 days old, the difference in tog values between infected index $(n=9)$ and control babies $(n=7)$ was $4 \cdot 8$ togs (range $2 \cdot 8-5 \cdot 5, p=0 \cdot 004)$ and for non-infected index $(n=32)$ and control babies $(n=75) 1 \cdot 8$ togs (range $0.5-3 \cdot 3, \mathrm{p}=0.014$ ).

A similar relationship was found between isolation of potential bacterial pathogens and tog values. Twenty index and nine control babies over 70 days old had bacterial pathogens isolated in significant quantities from the upper respiratory tract; none of these babies had viruses identified in the upper respiratory tract. The median tog values for the bacterial pathogen positive babies were: SUD victims $11 \cdot 1$ togs, controls $5 \cdot 6$, difference $5 \cdot 5$ togs $(95 \% \mathrm{CI}: 2 \cdot 0$ to $7.9, p<0.01)$. For the babies with no bacterial pathogens isolated, the median tog values were: SUD victims 10.3 togs, controls $8 \cdot 0$ togs, difference $=2 \cdot 3$ togs $(95 \% \mathrm{CI}: 0.1$ to $2 \cdot 8, \mathrm{p}<0 \cdot 05)$.

Analysis using a matched multiple logistic regression analysis for babies over 70 days old showed that there was a trend for virus infection to be associated with an increased risk of SUD: odds ratio $=2 \cdot 8$ ( $95 \% \mathrm{CI}: 0.98$ to $7 \cdot 9 ; \mathrm{p}>0.05$ ). When account was taken of the tog distribution, both virus infection (odds ratio $3 \cdot 7,95 \% \mathrm{CI}$ : 1.03 to 13.3 ) and clothing and bedding in excess of 10 togs compared with less than 6 togs (odds ratio $13 \cdot 7,95 \% \mathrm{CI}: 3 \cdot 2$ to $60 \cdot 6$ ) were significant, independent risk factors with no statistical interaction between them $\left(\chi^{2}=1.98\right)$; the relative risk for 6-10 togs was 3.9 (95\% CI: 0.99 to $15 \cdot 2$; $p>0.05)$. The relative risk associated with the combined presence of more than 10 togs of clothing and bedding and a viral infection compared with less than 6 togs and no viral infection was $51 \cdot 55$ (95\% CI: $5 \cdot 6$ to 471 ).

\section{SIGNS OF ILLNESS}

In both the index and control groups over 70 days old, there was no significant difference in tog values between babies with major signs of illness during the previous 24 hours (10/41 index and 6/82 controls) and those without (difference in togs for SUD victims $=0.6$ and for controls $=0.05 ; \mathrm{p}>0.05$ )

Major signs of illness during the previous week were more common among virus positive $(10 / 15)$ than virus negative $(24 / 80)$ SUD victims $\left(\chi^{2}=7 \cdot 3, p<0.01\right)$ but no such association could be demonstrated for the control babies.

We were unable to demonstrate the effect of the combination of prone position and viral infection as the number of infected babies was small and such a high proportion of the SUD victims $(63 / 68)$ slept prone.

\section{Discussion}

There were two distinct age groups within the SUD population, infection being much more common in index and control babies over 70 days of age. In this older age group, the combination of viral infection and clothing and bedding in excess of 10 togs was associated with a significantly increased risk of death.

Based on limited sampling from the upper 
respiratory and gastrointestinal tracts we did not show any significant excess of virus infection in the index group (16\%) compared with live control babies matched for age, time, and neighbourhood $(8 \%)$. The trend for viruses to be identified more commonly in the index group may have reached significance given a larger population. However, one important source of error was the fact that nasopharyngeal aspirates and intestinal mucosa specimens were analysed only in the index group. This is likely to have favoured more frequent identification of viruses in the index babies. Although virus infection did reach significance when the distribution of tog values was taken into account using a multiple logistic regression model, these borderline results indicate that viral infection alone can not be considered to be a major risk factor for SUD.

Bacterial pathogens were isolated more often from the upper respiratory tract of babies who died but there was no association between viral presence and isolation of bacterial pathogens at the same site. We are uncertain as to the significance of bacterial isolates at postmortem examination. Correlation with histological change is poor and it is possible that changes in bacterial flora occur as a result of, rather than before terminal asphyxia and death. It is of note that we were unable to confirm the association found by Bettelheim et al between toxigenic $E$ coli and SUD. ${ }^{22}$

According to our postmortem classification of findings in the index babies, infection provided an explanation for death (grade III) in 3/95 babies and may have contributed to death (grade II) in a further $37 / 95$. This classification is subjective and although postmortem control samples from babies dying suddenly from trauma would enable a more objective analysis of postmortem findings, such deaths are very rare and none occurred during our study. Nevertheless, our criteria could provide a basis for a more consistent classification of postmortem findings in SUD. ${ }^{10} 27$ An important advantage of our system is that, alongside the microbiological, histological, and metabolic classifications, other classifications can be added such as psychosocial factors, clinical factors or thermal stress, without distorting the overall categorisation of non-contributory (I), contributory (II), and causal disease (III).

On virological investigation of all organs, non-polio viruses were identified in 19/95 (20\%) of SUD victims, a similar proportion to that found in previous studies. ${ }^{1-5}$ It is of note that although the study period included two winters when respiratory syncytial virus infection was commonly identified in children admitted to hospital, we detected this virus in only one baby who died.

A striking finding was that the virus infected control babies had less clothing and bedding than the index babies and the non-infected control babies. This could not be explained by differing parental responses to illness as we found no correlation between reported major signs of illness and tog values of clothing and bedding in either the index or control groups. Another possible explanation is that light wrapping increased the risk of acquiring a viral infection while heavy wrapping increased the risk of death in the presence of infection.

Infection increases metabolic rate and can increase body temperature. The ability to lose heat in the presence of infection may therefore become critical in heavily wrapped babies. As $40 \%$ of total oxygen consumption in young infants is in the brain, the head is both a major site of heat production and the main effector organ for heat loss. ${ }^{28-30}$ Thus interference with heat loss from the head (for example by covers rising over it) could lead to temperature change in the brain without necessarily causing a corresponding rise in core body temperature. The consequences of such a rise in brain temperature are not known, but heat stress can lead to prolonged apnoea in both preterm ${ }^{31}$ and term infants..$^{32}$ Of our SUD victims, 23 wore a hat or were found with their head covered. Although no control babies wore hats, we have no data on how many had their heads covered by bedding at some time during the night.

Sudden unexpected infant death is undoubtedly caused by a variety of factors. In this and in a previous report ${ }^{12}$ we have shown that prone sleeping, heavy wrapping, the combination of prone sleeping and heavy wrapping, and the combination of viral infection and heavy wrapping are strongly associated with SUD. All three factors can cause thermal stress but their association with SUD is age related. ${ }^{12}$ The fact that infection and heavy wrapping are associated with death only in babies over 70 days old may indicate that these babies are physiologically less vulnerable and require more risk factors to precipitate death. Alternatively, older babies with their thicker subcutaneous layer of fat and higher ratio of metabolic rate to surface $\operatorname{area}^{33} 34$ may be more susceptible to thermal stress than younger babies for whom other mechanisms may be important.

Our case-control analysis was based on a small minority of babies with viral infection. Yet our postmortem classification showed that $37 / 95$ (38\%) SUD victims had evidence of recent infection which may have contributed to death. We speculate that the combination of infection and other environmental factors that cause thermal stress may contribute to death in over a third of SUD victims.

In babies over 70 days of age, the presence of a viral infection further increases the risk of death associated with heavy wrapping. The presence of a virus infection in the absence of heavy wrapping is not a major risk factor for sudden unexpected death.

We recommend that parents should pay particular attention to thermal care and avoid heavy wrapping, particularly if their baby has evidence of an infection. Avoidance of heat stress may be easier for babies nursed on their back or side. ${ }^{12}$ Parents should still be made aware of the need to avoid cold stress particularly as our results raise the possibility that lightly wrapped babies may be more likely to contract viral infections.

Further investigation is needed to ascertain appropriate clothing and bedding at different environmental temperatures and to define the 
effects of infections on metabolic rate and heat production in infancy.

We are grateful to Dr Yehu Azaz for help in data collection, Maggie Shapland for advice on data processing and computing, and $\mathrm{Dr}$ Jean Golding for help in planning and designing the study. RG was supported by a grant from the Foundation for the Study of Infant Deaths. Further financial support provided by Cow and Gate, Glaxo, and Avon Rubber.

1 Ray CG, Beckwith JB, Hebestreit NM Bergman AB. Studies of the sudden infant death syndrome in King County, of the sudden infant death syndrome in King County,

2 Urquhart GED, Grist NR. Virological studies of sudden, unexplained infant deaths in Glasgow 1967-70. F Clin Pathol 1972;25:443-6.

3 Patrick WJA, Carrington D, Armstrong AA, Gibson AAM, Urquhart GED. Eight year study of viral isolates from cot deaths in Glasgow. Scott Med f 1989;34:462-4.

4 Scott DJ, Gardner PS, McQuillin J, Stanton AN, Downham MAPS. Respiratory viruses and cot death. BMF 1978;ii: 12-3.

5 Williams AL, Uren EC, Bretherton L. Respiratory viruses and sudden infant death. BMF 1984;288:1491-3.

6 Sonnabend OAR, Sonnabend WFF, Krech U, Molz G Sigrist T. Continuous microbiological and pathological study of 70 sudden and unexpected infant deaths: toxigenic intestinal clostridum botulinium in 9 cases of sudden infant death syndrome. Lancet 1985; i:237-41.

7 Telford DR, Morris JA, Hughes P, et al. The nasopharyngeal bacterial flora in the sudden infant death syndrome. F Infect bacterial flora in

8 Annonymous. Respiratory infection and sudden infant death [Editorial]. Lancet 1989;ii:1191-2.

9 Berry PJ, Keeling JW. The investigation of sudden unexpected death in infancy. In: Anthony PP, MacSween RNM, eds. Recent advances in histopathology. London Churchill Livingstone, 1989:251-79.

10 Taylor EM, Emery JL. Categories of preventable unexpected infant deaths. Arch $D$ is Child 1990;65:535-9.

11 Gunn TR, Tonkin SL. Upper airway measurements during inspiration and expiration in infants. Pediatrics 1989;84: 73-7.

12 Fleming PJ, Gilbert R, Azaz Y, et al. Interaction between bedding and sleeping position in the sudden infant death syndrome: a population based case-control study. $B M \mathcal{F}$ 1990;301:85-9.

13 de Jonge GA, Engelberts AC, Koomen-liefting AJM, Kostense $\mathrm{PJ}$. Cot death and prone sleeping position in The Netherlands. BMF 1989;298:722.

14 Nelson EA, Taylor BJ, Mackay SC. Child care practices and the sudden infant death syndrome. Australian Paediatric the sudden infant dea

15 Dwyer T, Ponsonby ALB, Newman NM, Gibbons LE. Prospective cohort study of prone sleeping position and sudden infant death syndrome Lance 1991:337:1244-7.

16 Wigglesworth JS, Keeling JW, Rushton DI, Berry PJ.
Technical method. Pathological investigations in cases of sudden infant death $\mathcal{f}$ Clin Pathol 1987:40:1481-3.

17 Gilbert R, Fleming PJ, Azaz Y, Rudd PT. Signs of illness preceding sudden unexpected death in infants. $B M \mathcal{J}$ 1990;300:1237-9.

18 Skirrow MB. Campylobacter enteritis: a new disease. $B M \mathcal{F}$ 1977;ii:9-11.

19 Mills DC, Midura TF, Arnon SS. Improved selective medium for the isolation of lipase-positive Clostridium botulinum from feces of human infants. $\mathcal{F}$ Clin Microbio 1985;21:947-59.

20 Pugh SF, Slack RCB, Caul EO, Paul ID, Appleton PN, Gatley S. Enzyme amplified immunoassay: a novel technique applied to direct detection of Chlamydia trachomatis in clinical specimens. $\mathcal{I}$ Clin Pathol 1985;38:1139-41.

21 Taylor-Robinson D. Sexually transmitted diseases. Clin Lab Med 1989;9:501-23.

22 Bettelheim KA, Goldwater PN, Dwyer BW, Bourne AJ, Smith DL. Toxigenic Escherichia coli associated with sudden infant death syndrome. Scand F Infect Dis 1990;22:

23 Fleiss JL. Statistical methods for rates and proportions. Chichester: John Wiley, 1973:80-2.

24 Breslow NE, Day NE, Davis W, eds. Statistical methods in cancer research. Vol 1. Lyon: International Agency fo Research on Cancer, 1980:176-82.

25 Breslow NE, Day NE, Davis W, eds. Statistical methods in cancer research. Vol 1, appendix IV. Lyon: International Agency for Research on Cancer, 1980:298-306.

26 Beckwith JB. Discussion of terminology and definition of sudden infant death syndrome. In: Bergman AB, Beckwith $\mathrm{JB}$, Ray CG, eds. Proceedings of the second international conference on causes of sudden death in infants. Seattle: University of Washington Press, 1970.

27 Arneil GC, Gibson AAM, McIntosh H, Brooke H, Harvie A, Patrick WJA. National post-perinatal infant mortality and Patrick WJA. National post-perinatal infant mortality and

28 Nelson EAS, Taylor BJ, Weatherall IL. Sleeping position and infant bedding may predispose to hyperthermia and the and infant bedding may predispose to hyperthermia and

29 Wailoo MP, Petersen SA, Whittaker H, Goodenough P. Sleeping body temperatures in 3-4 month old infants. Arch Dis Child 1989;64:596-9.

30 Rutter N, Hull D. Response of term babies to a warm environment. Arch Dis Child 1979;54:178-83.

31 Perlstein PH, Edwards NK, Sutherland JM. Apnoea in premature infants and incubator-air-temperature changes. N Engl f Med 1970;282:461.

32 Gozal D, Colin AA, Daskalovic YI, Jaffe M. Environmenta overheating as a cause of transient respiratory chemoreceptor dysfunction in an infant. Pediatrics 1988;82: 738-40.

33 Azaz Y, Fleming PJ, Levine MR, McCabe R. The relationship between environmental temperature, metabolic rate and sleep state in infants from birth to two months (abst) Early Hum Dev 1989;18:293.

34 Haycock GB, Schwart GJ, Wisotsky DH. Geometric method for measuring body surface area: a height-weight method for measuring body surface area: a height-weight 1978;93:62-6. 